\title{
Rubber Dam Usage in Dentistry: A Review
}

\author{
Triveni Mohan Nalawade* and Buthaina Ali Humaid Aladawi \\ Oman Dental College, Muscat, Oman
}

Submission: November 01, 2017; Published: December 01, 2017

*Corresponding author: Triveni Mohan Nalawade, Oman Dental College, Muscat, Oman, Fax No. +96824665566;

Email: triveni_nalawade@rediffmail.com

\begin{abstract}
The objective of this article was to throw some light on the present scenario of rubber usage in dentistry. It has been seen through many questionnaire surveys in the past that the prevalence of rubber dam usage in dentistry has found to be low with some contradictions like United Kingdom and United States of America. So, the present study was conducted by reviewing the literature till date about usage of rubber dam in dentistry.
\end{abstract}

Keywords: Rubber dam; Isolation; Survey; Questionnaire; Education

Abbreviations: UK: United Kingdom; US: United States

\section{Introduction}

Rubber Dam was introduced almost 150 years back, and is unreplacable and is considered as a standard of care [1]. It is still the most ideal means of isolation till date [2]. It has many advantages as it improves visibility, prevents contamination from saliva, reflects the soft tissues, improves longetivity of the restoration[3,4], prevents trauma to soft tissues and also prevents ingestion of clamps, crowns, endodontic files [5,6,7]. In spite of these numerous advantages, it is observed from many questionnaire studies that rubber dam usage is not regular $[8,9,10]$. In some countries like the UK and US studies have contradictory findings with recent studies showing a higher percentage of use of rubber dam in dentistry. Recently a study in Saudi Arabia highlighted the usage to be less from Dentists in a few countries and the reason being lack of under graduate training and facilities too [7].

\section{Discussion}

In some countries, like the United Kingdom and United States there is gradual increase in the trend of usage of rubber dam [7], which is gives hope that even though many studies show that rubber dam has been always rejected by the dental professionals; times are definitely changing. Rubber Dam usage has been low whether it be Endodontics [6,7,10,11] Pediatric Dentistry [12], Restorative dentistry $[3,4]$ or general dentistry $[8,9]$.

There have been studies in different parts of the world and except for US and UK in recent years all show low prevalence of rubber dam usage during dental treatment. Even in US study by
Hill and Rubel in 2008 among general dentists and found the usage of rubber dam low [13]. Similarly, in UK studies by Whitworth et al, Jenkins et al. \& Palmer NO et al. revealed low use of rubber dam isolation. Koch et al. [7] conducted a survey in Sweden and found that more than $90 \%$ of general dentists used rubber dam for isolation. A study among Irish general dental practitioners by Lynch et al in 2007 revealed limited use of rubber dam in operative as compared to endodontics [9]. A study by Kapitan \& Sustova [14] in 2011 in Czech Republic amongst dentists again reflected low usage of rubber dam.

A study in Australia by Burke et al in 2004 revealed that 36 per cent never used rubber dam [15]. Two studies by Chiang [16] and Lin et al. [17] found low prevalence of rubber dam isolation during endodontic treatment in both private and hospital settings in national health insurance system in Taiwan. A study in the eastern state of Odisha in India in 2014 revealed a low prevalence of rubber dam usage [18]. In 2016, a study in Saudi Arabia highlighted that rubber dam usage was still not used regularly in general dental practices but its use was on the rise [7].

On the contrary, when studies were conducted on undergraduate students in Saudi Arabia in 2017 they showed a better and positive attitude towards rubber dam isolation. The prevalence of rubber dam usage was low in Indian undergraduate final year students in 2014. So with change of time, younger generations of dentists and idealistic views usage of rubber dam might get influenced positively. Also, was an interesting fact that rubber dam was being used more often in the government sector 
as in the study in Saudi Arabia due to greater facilities, availability of rubber dam armamentarium and motivation to follow high standards regulations. Another interesting fact was that peer pressure could positively elevate rubber dam usage as observed in group practice as compared to solo practices [7].

\section{Conclusion}

As we conclude this mini-review on rubber dam usage in dentistry, we truly agree with the findings of Madarati et al:

1. Rubber dam usage is still low throughout the world but with a few exceptions like US and UK times are changing.

2. Place of work ie., government set ups and group practices are better in terms of rubber dam usage prevalence due to better facilities, regulations and peer pressure.

3. Undergraduates are more motivated, are adapting to new advancements and trying to follow standard of care in dental practice.

4. So, better dental education, training, motivation and regulations might help to improvise rubber dam usage in general dental practices.

\section{References}

1. Glickman GN, Vogt MW (2011) Preparation for treatment. In: Hargreaves KM, et al. (Eds.), Cohen's Pathways of the Pulp. (10 ${ }^{\text {th }}$ edn.), Mosby: 88-123.

2. European Society of Endodontology (2006) Quality guidelines for endodontic treatment: Consensus report of the European Society of Endodontology. Int Endod J 39(12): 921-30.

3. Keys W, Carson SJ (2017) Rubber dam may increase the survival time of dental restorations. Evid Based Dent 18(1): 19-20.

4. Wang Y, Li C, Yuan H, Wong MC, Zou J, et al. (2016) Rubber dam isolation for restorative treatment in dental patients. Cochrane Database Syst Rev CD009858.
5. Heling B, Heling I (1977) Endodontic procedures must never be performed without the rubber dam. Oral Surg Oral Med Oral Pathol 43(3): 464-466.

6. Ahmed HM, Cohen S, Lévy G, Steier L, Bukiet F (2014) Rubber dam application in endodontic practice: an update on critical educational and ethical dilemmas. Aust Dent J 59(4): 457-463.

7. Madarati AA (2016) Why dentists don't use rubber dam during endodontics and how to promote its usage? BMC Oral Health 16: 24.

8. Udoye CI, JafarzadehH (2010) Rubber dam use among a subpopulation of Nigerian dentists. J Oral Sci Jun 52(2): 245-249.

9. Lynch CD, McConnell RJ (2007) Attitudes and use of rubber dam by Irish general dental practitioners. Int Endod J 40(6): 427-432.

10. Lin HC, Pai SF, Hsu YY, Chen CS, Kuo ML, et al. (2011) Use of rubber dams during root canal treatment in Taiwan. J Formos Med Assoc 110(6): 397-400.

11. Ahmad IA (2009) Rubber dam usage for endodontic treatment: a review. IntEndod J 42(11): 963-972.

12. Schorer-Jensma MA, Veerkamp JS. (2010) A comparison of paediatric dentists' and general dental practitioners' care patterns in paediatric dental care. Eur Arch Paediatr Dent 11(2): 93-96.

13. Hill EE, Rubel BS. (2008) Do dental educators need to improve their approach to teaching rubber dam use? J Dent Educ 72(10): 1177-1181.

14. Kapitán M, Sustová Z (2011) The use of rubber dam among Czech dental practitioners. Acta Medica (Hradec Kralove). 54(4): 144-148.

15. Burke FJ, McHugh S, Randall RC, Meyers IA, Pitt J, et al. (2004) Direct restorative materials use in Australia in 2002. Aust Dent J 49(4): 185191.

16. Chiang CP. (2012) Low prevalence of rubber dam usage for root canal treatment in Taiwan. J Formos Med Assoc 111(11): 660.

17. Lin HC, Pai SF, Hsu YY, Chen CS, Kuo ML, et al. (2011) Use of rubber dams during root canal treatment in Taiwan. J Formos Med Assoc 110(6): 397-400.

18. G S, Jena A, Maity AB, Panda PK. (2014) Prevalence of Rubber Dam Usage during Endodontic Procedure: A Questionnaire Survey. J Clin Diagn Res 8(6): ZC01-ZC03.

\section{Your next submission with Juniper Publishers will reach you the below assets}

- Quality Editorial service

- Swift Peer Review

- Reprints availability

- E-prints Service

- Manuscript Podcast for convenient understanding

- Global attainment for your research

- Manuscript accessibility in different formats

( Pdf, E-pub, Full Text, Audio)

- Unceasing customer service

Track the below URL for one-step submission https://juniperpublishers.com/online-submission.php 